\title{
Effect of Multiple Consecutive Adhesive Coatings on Microleakage of Class V Cavities
}

\author{
Hacer Deniz Arisua \\ Evrim Eliguzeloglu \\ Mine Betul Uctaslic \\ Huma Omurlud \\ Emin Turkoz
}

\section{ABSTRACT}

Objectives: The purpose of this in vitro study was to evaluate the effect of multiple consecutive adhesive coatings of a one-step self-etch adhesive on microleakage of Class $V$ cavities.

Methods: Standardized box shaped Class V cavities were prepared onto the buccal side of forty five non-carious human premolar teeth. The teeth were randomly divided into three groups of fifteen teeth in each and restored as: Group I- one-step self-etch adhesive resin (Clearfil S3, Kuraray Co. Ltd., Osaka, Japan) was applied according to the manufacturer's instructions, Group II- two consecutive same one-step self-etch adhesive application was performed, and Group III- three consecutive same one-step self-etch adhesive application was performed. After the adhesive applications light curing unit was activated for 20 seconds and the cavities were restored with a composite resin. The restorations were finished with aluminum oxide discs and the specimens were stored in water at room temperature for 24 hours before they were immersed in $2 \%$ methylene blue for 48 hours. The dye penetration was examined under a stereomicroscope and the asymtotic significance were analysed with Kruskall Wallis and Mann Whitney $\mathrm{U}$ tests and dentin-enamel margins were compared with each other with Wilcoxon Signed Rank test.

Results: The microleakage at the dentinal margins of Class $V$ cavities were significantly decreased with two (Group II) and three (Group III) consecutive adhesive applications $(P<.05)$. There was no significant difference between Group I, Group II and Group III at the enamel margins ( $P<.05)$. The microleakage at the dentinal margins were significantly higher than the enamel margins in Group I and Group II but in Group III there was no statistically significant difference $(P<.05)$.

Conclusions: Within the limitations of this in vitro study, it may be concluded that three consecutive applications of the one-step self-etch adhesive resin provided better sealing than the one coat of adhesive resin at the dentinal margins of Class V cavities. (Eur J Dent 2009;3:178-184)

Key words: Dentin bonding; Microleakage; Self-etch adhesive; Class V cavity.

a Lecturer, University of Gazi, Faculty of Dentistry, Department of Operative Dentistry \& Endodontics, Ankara, Turkey.

b Specialist, University of Gazi, Faculty of Dentistry, Department of Operative Dentistry \& Endodontics, Ankara, Turkey.

Assistant Professor, University of Gazi, Faculty of Dentistry, Department of Operative Dentistry \& Endodontics, Ankara, Turkey. d Professor, University of Gazi, Faculty of Dentistry, Department of Operative Dentistry \& Endodontics, Ankara, Turkey.

- Corresponding author: Hacer Deniz Arisu University of Gazi, Faculty of Dentistry, Department of Operative Dentistry \& Endodontics 8. Cadde 82. Sokak 06510 Emek-Ankara / TURKEY

Phone: + 903122034123 Fax: +90 3122239226

E-mail: uctasli@gazi.edu.tr 


\section{INTRODUCTION}

Dentin adhesives and resin-based composites have been widely used for restoring Class $V$ cavities because of the increasing demand for esthetic restorations in daily clinical dentistry. ${ }^{1}$ These cavities are extended different bonding substrates, enamel at the occlusal and dentin at the gingival margins. Bonding of resins to dentin is more difficult and less predictable than bonding to enamel because dentin includes fewer mineral but more organic and water content than enamel. A cohesive bond to dentin is achieved by diffusion of hydrophilic resins into and around the collagen fibers of etched intertubular dentin. Complete penetration into the entire depth of the demineralized zone is necessary to prevent bacterial microleakage and recurrent caries. ${ }^{2}$

The initial effectiveness and durability of the interface between the resin composite and tooth tissues may be described as a simple relationship between the bond strength and the stress generated by polymerization shrinkage. With time, stresses caused by other factors such as occlusal loading and thermal changes will add to the process. To ensure a successful restorative procedure the bonded interface area must be capable of withstanding those stresses. The elastic modulus of the restorative composite has been reported to be an important factor for the generation of shrinkage stresses: as the elastic modulus increases, more shrinkage stress transmitted to the interface with less relief. ${ }^{3}$ The hybrid layer has a relatively low elastic modulus to relieve polymerization shrinkage stresses that work as a stress absorbing layer. However, it is not thick as the bonding resin lying adjacent. ${ }^{4}$

Several studies have recently shown that despite the simplified approach of all-in-one adhesives they do not necessarily promote an effective seal of dentin. ${ }^{5-8}$ This inferior performance has been attributed to certain factors. First, these products create very thin coatings, 9,10 which may be oxygen inhibited, resulting in a poorly polymerized adhesive layer. ${ }^{11}$ Second, they are highly prone to phase separation ${ }^{12}$ as the solvent evaporates from the solution and, finally, they behave as permeable membrane after polymerization. ${ }^{13}$ Some authors have indicated that treating onestep self-etch systems as a primer and covering them with a less hydrophilic resin coating can be an option for resolving their drawbacks. ${ }^{14,15}$ Other authors, however have suggested placing multiple layers in a clinical attempt to improve their clinical efficacy. ${ }^{9,10,16}$

The aim of this in vitro study was to evaluate the effects of multiple consecutive adhesive coatings of an one-step self-etch adhesive on the microleakage of high configuration factor cavities (Class V) just after restorations were completed. The null hypothesis tested was that multiple consecutive applications of resin have no effect on microleakage of Class $\mathrm{V}$ restorations.

\section{MATERIALS AND METHODS}

A total of 45 extracted human premolars without decay, cracks or previous restorations, which were scaled and cleaned with slurry of pumice flour were used in this study. Standard Class V cavities $14 \mathrm{~mm}$ width, $4 \mathrm{~mm}$ height, $2 \mathrm{~mm}$ depth) were prepared with a high speed handpiece at the cemento-enamel junction on the buccal surfaces of premolar teeth. Occlusal margins were cut in enamel and cervical margins in cementum. One commercially available, one-step self-etch adhesive (Clearfil S, Kuraray Co. Ltd., Osaka, Japan) was used in this study. All prepared teeth were allocated into 3 equal groups of 15 teeth in each in a random manner. The teeth were restored as: Group I- adhesive resin was applied according to the manufacturer's instructions (Table 1) Group II- two consecutive adhesive applications were performed Group III- three consecutive adhesive applications were performed. For multiple consecutive applications (Group 2 and 3) adhesive application and solvent evaporation with gentle air spraying for 5 seconds steps were done repeatedly but without any light curing until all layers have been applied. After the adhesive applications, a LED light curing unit (Elipar Frelight II, Dentsply, Kontstanz, Germanyl was placed to the buccal surfaces at close range $(0-1 \mathrm{~mm})$ and activated at $1000 \mathrm{~mW} / \mathrm{cm}^{2}$ for 20 seconds. The cavities were restored with a commercially available composite resin (Clearfil APX, Kuraray Co. Ltd., Osaka, Japan). The restorations were finished with aluminum oxide discs (Sof-Lex, 3M ESPE Dental Products, St. Paul, MN, USA). Teeth were thermocycled for 500 cycles between $5^{\circ} \mathrm{C}$ and $55^{\circ} \mathrm{C}$, dwell time of 30 seconds and a transfer time of three seconds. The specimens were sealed with sticky wax at the root 
apices and all external surfaces were isolated with two layers of nail varnish except $1 \mathrm{~mm}$ around the restorations. The specimens were stored in water at room temperature for 24 hours before they were immersed in $2 \%$ methylene blue for 48 hours. The specimens were rinsed under tap water and dried. Teeth were sectioned in 3 portions faciolingually with a low speed saw (Mecatome T201A, Pressi, France). Sections were assessed for dye penetration with a stereomicroscope (Nikon Eclips E600, Tokyo, Japan) at a x20 magnification at the occlusal and cervical margins. Two investigators blindly scored all interfaces and the mean score was recorded. Approximately forty two scores for dentinal margins and forty two scores for enamel margins were recorded from three sections of each group, some sections were missed during the cutting process and they were recorded as missing value. Dye penetration at the composite/ tooth interface was scored for both dentinal and enamel margins on a nonparametric scale from 0 to 3 as:

$0=$ no microleakage $;=$ dye penetration less than $1 / 2$ of axial wall; $2=$ dye penetration more than $1 / 2$ of axial wall; $3=$ dye penetration spreading along the axial wall.17

Asymptotic significance was analyzed using Kruskall Wallis and Mann Whitney $U$ tests and

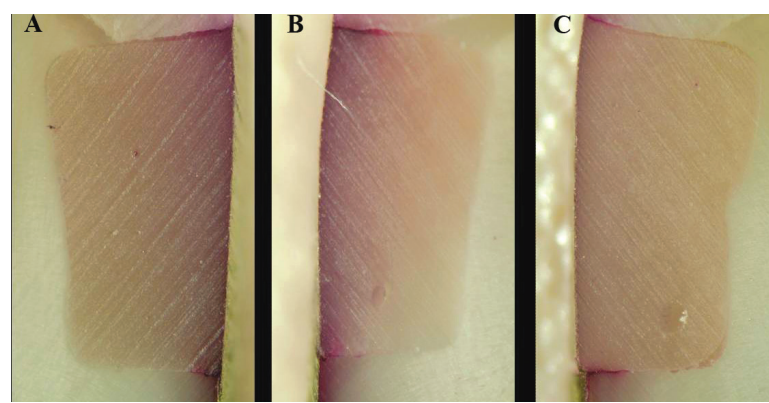

Figure 1. Representative microleakage photographs of one coat of adhesive application group (Group I) from mesial (A), middle (B), distal (C) sections.

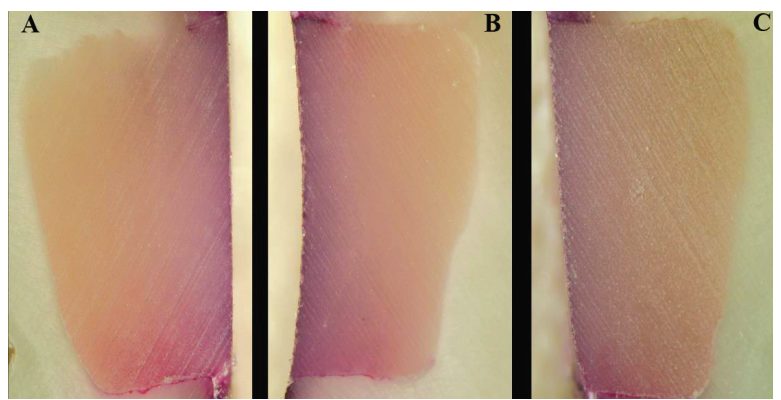

Figure 2. Representative microleakage photographs of two coats of adhesive applications group (Group II) from mesial (A), middle $(B)$, distal $(C)$ sections. dentin-enamel margins were compared with each other with Wilcoxon Signed Rank test.

\section{RESULTS}

The frequency and descriptive statistics and significant differences of the microleakage scores obtained from groups are given in Table 2 , Table 3 and Table 4. Representative microleakage photographs $(\times 20)$ of groups are presented in Figure 1 to 3.

The microleakage at the dentinal margins of Class $V$ cavities were significantly decreased with two (Group II) ( $\mathrm{P}=0.003)$ and three (Group III) $(P=0.000)$ consecutive adhesive applications when compared with Group I, but there was no significant difference between Group II and Group III $(P=0.169)$. However, there was no significant difference between, Group I, Group II (P=0.834), Group I, Group III (P=0.651) and Group II, Group III $(P=0.356)$ in the enamel margins.

The microleakage at the dentinal margins were significantly higher than the enamel margins in Group I ( $P=0.000)$ and Group II ( $P=0.000)$ but in Group III three consecutive adhesive applications were significantly decreased the microleakage in dentinal margins so there was no statistically significant difference $(P=0.051)$ between enamel and dentinal marginal microleakage scores in this group.

\section{DISCUSSION}

Clinical trials remain the gold standard in evaluating the performance of dental materials but it must also take into consideration that the products under investigation may become absolute by the time useful clinical data are collected. Thus, preclinical screening via laboratory tests is still an important tool for the evaluation of dentin adhesives. ${ }^{18}$ Clinicians and researchers
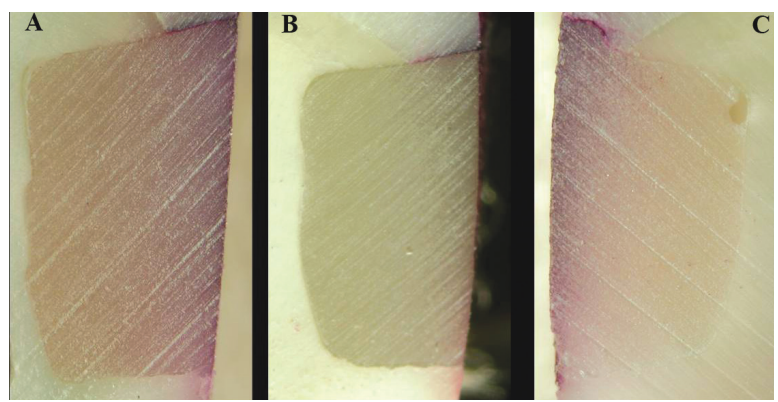

Figure 3. Representative microleakage photographs of three coats of adhesive applications group (Group III) from mesial $(A)$, middle (B), distal (C) sections. 
use microleakage as a measure for assessing the performance of restorative materials in the oral environment. Different techniques are used for microleakage evaluation, but the most employed method is the migration of dye along the tooth/restoration interface. ${ }^{19-21}$ Although this method is simple, economic, and fast technique, the subjectivity of reading the specimens has been noted as a shortcoming related to this methodology. 22

Despite the continuing evaluation of adhesive systems, up to now no available adhesive technique can produce predictable results when the preparation margins are located in dentin. ${ }^{22-24}$ Contraction stresses generated during placement of a composite restoration contribute significantly to early marginal leakage, especially in dentin. ${ }^{25}$ The lower bond strength obtained in dentin is not strong enough to counteract the stress developed during polymerization shrinkage which impairs the sealing capacity. ${ }^{26}$ The conventional Class $\mathrm{V}$ cavity employed in this study represents a great challenge to the adhesive systems used due to the high $\mathrm{C}$-factor. ${ }^{27,28}$

In the present study, higher leakage was detected in dentin when compared to enamel in

Table 1. Composition and application steps for Clearfil S3.

\begin{tabular}{|c|c|c|}
\hline Material and manufacturer & Composition & $\begin{array}{c}\text { Manufacturer recommendation } \\
\text { for adhesive application }\end{array}$ \\
\hline $\begin{array}{l}\text { Clearfil S3 Bond } \\
\text { (Kuraray Co. Ltd., Osaka, Japan) }\end{array}$ & $\begin{array}{c}\text { Water, MDP, bis-GMA, HEMA, } \\
\text { hydrophobic DMA, CQ, ethyl alcohol, } \\
\text { silanated colloidal silica }\end{array}$ & $\begin{array}{l}\text { Apply bond and wait } 20 \text { seconds, } \\
\text { dry with high-pressure air for } \\
5 \text { seconds and light cure for } 10 \\
\text { seconds. }\end{array}$ \\
\hline
\end{tabular}

Table 2. Frequency table of the microleakage scores obtained from the groups.

\begin{tabular}{lccccccccc}
\hline & \multicolumn{3}{c}{ Enamel margins } & \multicolumn{5}{c}{ Dentinal margins } \\
\hline Groups (n) & 0 & 1 & 2 & 3 & 0 & 1 & 2 & 3 \\
\hline Group I (40) & 11 & 15 & 12 & 2 & 3 & 2 & 8 & 27 \\
\hline Group II (43) & 6 & 28 & 9 & - & 5 & 8 & 16 & 14 \\
\hline Group III (43) & 1 & 33 & 9 & - & 12 & 10 & 7 & 14 \\
\hline
\end{tabular}

Table 3. Descriptive statistics of the microleakage scores of groups.

\begin{tabular}{|c|c|c|c|c|c|c|c|}
\hline & Groups & $\mathrm{N}$ & Min & Max & Median & Mean & Std. Dev. \\
\hline \multirow{3}{*}{ Enamel margins } & Group I & 40 & 0 & 3 & 1.00 & 1.13 & .883 \\
\hline & Group II & 43 & 0 & 2 & 1.00 & 1.07 & .593 \\
\hline & Group III & 43 & 0 & 2 & 1.00 & 1.19 & .450 \\
\hline \multirow{3}{*}{ Dentinal margins } & Group I & 40 & 0 & 3 & 3.00 & 2.48 & .905 \\
\hline & Group II & 43 & 0 & 3 & 2.00 & 1.91 & .996 \\
\hline & Group III & 43 & 0 & 3 & 1.00 & 1.53 & 1.222 \\
\hline
\end{tabular}

Table 4. Significant differences and similarities between groups.

\begin{tabular}{lcc}
\hline Groups & Enamel margins & Dentinal margins \\
\hline Group I & $a A$ & $a B$ \\
Group II & aA & $b B$ \\
Group III & aA & $b A$ \\
\hline
\end{tabular}

* Lower cases represent significant difference between the groups, capitals represent the significant difference between the enamel and dentin margins. 
Group I and II. This finding is in agreement with some authors who used different combinations of dentin bonding agents and resin based composites in both Class II and Class V restorations ${ }^{29-32}$ but in Group III there was no difference in enamel and dentinal margins $(P=0.049)$ and this finding is due to the decreased microleakage at the dentinal margins and increased microleakage in enamel margins after three consecutive adhesive applications. The higher leakage scores detected in dentin when compared to enamel in Group I and II, can be related to the composition of these two tissues. Bonding to enamel is relatively simple process without major technical requirements or difficulties. On the other hand, bonding to dentin presents a much greater challenge. Several factors account for these difference between enamel and dentin bonding whereas enamel is a highly mineralized tissue composed of more than $90 \%$ (by volume) hydroxyapatite. Dentin contains a substantial proportion of water and organic materials, it presents a moist surface which impairs the bonding mechanism. ${ }^{33}$ The repeated procedure of adhesive application and subsequent solvent evaporation may promote improved resin infiltration and cross-linking of adhesive comonomers within the exposed collagen fibrils.

The leakage scores at the dentinal margins were significantly decreased with two and three consecutive coats of adhesive applications but the minimal microleakage was observed in three consecutive coats by the repeated application of the adhesive resin without light curing. Repeated application and subsequent solvent evaporation with longer resin application times may promote improved resin infiltration of total-etch adhesives within the exposed collagen fibers and increase resin-dentin bond strength. ${ }^{25,34}$ The use of multiple applications of adhesives without curing allows more time for removal of water from the interfibriller spaces and more time for the resin infiltration of the hybrid layer without increasing the thickness of the overlying adhesive layer.

Another factor about reduced microleakage with two and three consecutive coats of adhesive application at dentin margins may be the chemical composition of Clearfil S3. Clearfil S3 is a filled adhesive, it contains colloidal silica particles. Multiple application of filled adhesive Clearfil S3, increase the amount of the fillers and the thickness of the hybrid layer so, this layer can compensate polymerization stress occurred between composite and dentin.

Different research centers have shown that, the enamel surfaces were poorly demineralized by the one-step self etch adhesives. ${ }^{35,36}$ Alternative bonding strategies, such as increasing the acidic nature of self etch adhesives, ${ }^{37,38}$ acid etching with phosphoric acid before self etch adhesives,39 multiple applications ${ }^{40}$ or increased substrate contact time of self etch adhesives ${ }^{41}$ may also helpful in achieving a better link between the adhesive and enamel surfaces. In the present study sealing capacity of multiple applications of self etch adhesive was investigated and no significant difference was determined between the groups at the enamel margins. So we can say that multiple self etch adhesive application is not useful for enamel surfaces.

\section{CONCLUSIONS}

Within the limitations of this in vitro study, it may be concluded that three consecutive applications of the one-step self-etch adhesive resin provided better sealing than the one coat of adhesive resin at the dentinal margins of Class $V$ cavities.

\section{ACKNOWLEDGEMENTS}

This study was presented in 7. Aegean Region Chambers of Dentists International Scientific Congress and Exhibition, Fethiye, 2007.

\section{REFERENCES}

1. Van Meerbeek B, De Munck J, Yoshida Y. Buonocure memorial lecture. Adhesion to enamel and dentin: current status and future challenges. Oper Dent 2003;28:215-235.

2. Ben-Amar A, Pilo P, Shapinko E, Lewinstein I. A microleakage study of single-bottle adhesives applied to enamel and cementum and aged by both occlusal loading and thermocycling. Quint Int 2005;36:177-182.

3. Feilzer AJ, de Gee AJ, Davidson CL. Relaxation of polymerization contraction shear stress by hygroscopic expansion. J Dent Res 1990;69: 36-39.

4. Swift EJ Jr, Triolo PT Jr, Barkmeier WW, Bird JL, Bounds SJ. Effect of low-viscosity resins on the performance of dental adhesives. Am J Dent 1996;9:100-104.

5. Inoue S, Vargas MA, Abe Y, Yoshida Y, Lambrechts $P$, Vanherle G, Sano H, Van Meerbeek B. Microtensile bond strength of eleven contemporary adhesives to enamel. $\mathrm{Am}$ J Dent 16;329-334. 
6. Brackett WW, Ito S, Nishitani Y, Haisch LD, Pashley DH. The microtensile bond strength of self-etching adhesives to ground enamel. Oper Dent 2006;31:332-337.

7. Tay FR, Pashley DH. Water treeing - a potential mechanism for degradation of dentin adhesives. Am J Dent 2003;16:612.

8. Osoiro R, Toledano M, De Leonardi G, Tay F. Microleakage and interfacial morphology of self etching adhesives in Class V resin composite restorations. J Biomed Mater Res B Appl Biomater 2003;66:399- 409.

9. Frankenberger R, Perdigao J, Rosa BT, Lopes M. No-bottle vs multiple bottle dentin adhesives- a microtensile bond strength and morphological study. Dent Mater 2001;17:373380.

10. Pashley EL, Agee KA, Pashley DH, Tay FR. Effects of one versus two applications of an unfilled, all-in one adhesive on dentin bonding. J Dent 2002;30:83-90.

11. Rueggeberg FA, Margeson DH. The effect of oxygen inhibition on an unfilled/filled composite system. J Dent Res 1990;69:1652-1658.

12. Van Landuyt KL, De Munck J, Snauwaert J, Coutinho E, Poitevin A, Yoshida Y, Inoue S, Peumans M, Suzuki K, Lambrechts P, Van Meerbeek B. Monomer solvent phase separation in one step self etch adhesives. J Dent Res 2005;84:183-188.

13. Tay FR, Pashley DH, Suh BI, Carvalho RM, Itthagarun A. Single step adhesives are permeable membranes. J Dent 2002;30:371-382.

14. King NM, Tay FR, Pashley DH, Hoshimoto M, Ito S, Brackett WW, Garcia-Godoy F, Sunico M. Conversion of one-step to two-step self-etch adhesives for improved efficacy and extended applications. Am J Dent 2005;18:126-134.

15. Brackett WW, Ito S, Tay FR, Haisch LD, Pashley DH. Microtensile dentin bond strength of self-etching resins: Effect of hydrophobic layer. Oper Dent 2005;30:733-738.

16. Ito S, Tay FR, Hashimoto M, Yoshiyama M, Saito T, Brackett WW, Waller JL, Pashley DH. Effects of multiple coatings of two all-in-one adhesives on dentin bonding. J Adhes Dent 2005;7:133-141.

17. Arisu HD, Uctasli MB, Eliguzeloglu E, Ozcan S, Omurlu H. The effect of occlusal loading on the microleakage of class V restorations. Oper Dent 2008;33:135-141.

18. Braem M, Lambrechts $P$, Vanherle $G$. Clinical relevance of laboratory fatigue studies. J Dent 1994;22:97-102.

19. Raskin A, D'Hoore W, Gonthier S, Degrange M, Dejou J. Reliability of in vitro microleakage tests: a literature review. J Adhes Dent 2001;3:295-308.

20. Alani AH, Toh CG. Detection of microleakage around dental restorations: A review. Oper Dent 1997;22:173-185.

21. Taylor MJ, Lynch E. Microleakage. J Dent 1992;20:3-10.
22. Demarco FF, Ramos OLV, Mota CS, Formolo E, Justino LM. Influence of different restorative techniques on microleakage in class II cavities with gingival wall in cementum. Oper Dent 2001;26:253-259.

23. Santini A, Ivanovic V, Ibbetson R, Millia E. Influence of cavity configuration on microleakage around class $\mathrm{V}$ restorations bonded with seven self-etching adhesives. $J$ Esthet Restor Dent 2004;16;128-135

24. Piva E, Meinhardt L, Demarco FF, Powers JM. Dyes for caries detection: influence on composite and compomer microleakage. Clin Oral Investig 2002;6:244-248.

25. el-Din AKN, Abd el-Mohsen MM. Effect of changing application times on adhesive systems bond strengths. $\mathrm{Am}$ $J$ Dent 2002;15:321-324.

26. Davidson CL, Feilzer AJ. Polymerization shrinkage and polymerization shrinkage stress in polymer-based restoratives. J Dent 1997;25:435-440.

27. Burke FJ, McCaughey D. The four generations of dentin bonding. Am J Dent 1995;8:88-92.

28. Carvalho RM, Pereira JC, Yoshiyama M, Pashley DH. A review of polymerization contraction: the influence of stress development versus stress relief. Oper Dent $1996 ; 21: 17-24$.

29. Castelnuovo J, Tjan AH, Liu P. Microleakage of multistep and simplified step systems. Am J Dent 1996;9:269-272.

30. Choi KK, Condon JR, Ferracane JL. The effects of adhesive thickness on polymerization contraction stress of composite. J Dent Res 2000;79:812-817.

31. Saunders WP, Saunders EN. Microleakage of bonding agents with wet and dry bonding techniques. Am J Dent 1996;9:34-36

32. Cvitko E, Denehy G, Boyer DB. Effect of matrix systems and polymerization techniques on microleakage of Class II resin composite restorations. Am J Dent 1992;5:321-323.

33. De Munk J, Van Landuyt K, Peumans M, Poitevin A, Lambrechts $P$, Braem M, van Meerbeek B. A critical review of the durability of adhesion to tooth tissue: methods and results. J Dent Res 2005;84:118-132.

34. Hashimoto M, Sano H, Yoshida E, Hori M, Kaga M, Oguchi $\mathrm{H}$, Pashley $\mathrm{DH}$. Effects of multiple adhesive coatings on dentin bonding. Oper Dent 2004;29:416-423.

35. Albuquerque M, Pegoraro M, Mattei G, Reis A, Loguercio AD. Effect of double application or the application of a hydrophobic layer for improved efficacy of one step self etch systems in enamel and dentin. Oper Dent 2008;33:564570.

36. Tay FR, Pashley DH, King NM, Carvalho RM, Tsai J, Lai SCN, Marquezini L, Jr. Aggressiveness of self-etch adhesives on unground enamel. Oper Dent 2004;29:309-316. 
37. Pashley DH, Tay FR. Aggressiveness of contemporary selfetching adhesives. Part II: Etching effects on unground enamel. Dent Mater 2001;17:430-444.

38. Tay FR, Pashley DH. Aggressiveness of contemporary selfetching adhesives. I: Depth of penetration beyond smear layers. Dent Mater 2001;17:296-308.

39. Toledano M, Proenca JP, Erhardt MCG, Osorio E, Aguilera FS, Osorio R, Tay FR. Increases in dentin bond strength if doubling application time of an acetone containing one step adhesive. Oper Dent 2007;32:133-137.

40. Ogata M, Nakajima M, Sano H, Tagami J. Effect of dentin primer application on regional bond strength to cervical wedge-shaped cavity walls. Oper Dent 1999;24:81-88.

41. Ferrari M, Mannocci F, Vichi A, Davidson CL. Effect of two etching times on the sealing ability of Clearfil Liner Bond 2 in Class V restorations. Am J Dent 1997;10:66-70. 